\title{
Soil Stabilization with Lime for the Construction of Forest Roads
}

\author{
Reginaldo Sérgio Pereira ${ }^{1}$, Fabiano Emmert ${ }^{2}$, Eder Pereira Miguel ${ }^{1}$, \\ Alcides Gatto ${ }^{1}$ \\ ${ }^{1}$ Departamento de Engenharia Florestal, Universidade de Brasília - UnB, Brasília/DF, Brazil \\ ${ }^{2}$ Instituto de Ciências Agrárias, Universidade Federal Rural da Amazônia - UFRA, Belém/PA, Brazil
}

\begin{abstract}
The mechanical performance of soil stabilization using lime to improve forest roads was assessed. This study was conducted with lateritic soil (LVAd30) using lime content of $2 \%$ in the municipality of Niquelândia, Goiás state, Brazil. Geotechnical tests of soil characterization, compaction, and mechanical strength were performed applying different compaction efforts and curing periods. The results showed that lime content significantly changed the mechanical performance of natural soil, increasing its mechanical strength and load-carrying capacity. Compaction effort and curing time provided different responses in the unconfined compressive strength (UCS) and California Bearing Ratio (CBR) tests. The best UCS value (786.59 kPa) for the soil-lime mixture was achieved with modified compaction effort and curing time of 28 days. In the CBR test, soil-lime mixtures compacted at intermediate and modified efforts and cured for 28 days were considered for application as subbase material of flexible road pavements, being a promising alternative for use in layers of forest roads.
\end{abstract}

Keywords: flexible pavements, forest transportation, lateritic soil, forest management. 


\section{INTRODUCTION}

A network of forest roads with adequate surfacing is essential to maintain a continuous flow of timber transportation from planted forests in Brazil. Due to the increased demand for wood by the business sector, the traffic of heavy cargo trucks with a payload greater than 40 tons is increasingly intense along these routes. This finding has led to the need to build roads with good load-bearing capacity and durability.

According to Sessions (2007), forest roads present a differentiated structure in their cross-section compared to national public highways. Forest roads are constructions with two almost indistinguishable layers (a subgrade or natural soil and an improved layer) and both must bear the demands of the transport of wood and resist climatic adversities, especially during the rainy season. To deal with these conditions, forest roads require good construction techniques and materials, which are usually local soils.

In Brazil, lateritic soils, such as Oxisols, are predominant. These soils are rich in iron and aluminum and were formed by geological processes through tropical weathering. Due to their wide availability, they are a cheaper option and a more common material for road construction for timber transportation from forest plantations. However, roads built with such materials are subject to deterioration owing to their poor geotechnical and mechanical attributes when carrying intense traffic, as well as during the rainy season (Millogo et al., 2012). In this context, Portelinha et al. (2012) highlighted the use of chemical stabilization techniques using lime as an economical alternative for soil improvement. Lime is one of the oldest road construction materials (Dash \& Hussain, 2012), whose technological characterization as a soil stabilizing agent was referenced in studies by Machado et al. (2006), Consoli et al. (2009), and Cristelo et al. (2009). Lime can increase the mechanical performance of local soils for use in layers of flexible pavements.

Therefore, the objective of the present study was to investigate, using laboratory geotechnical assays, the technical potential of the use of hydrated lime in the improvement of soil engineering properties of forest roads.

\section{MATERIAL AND METHODS}

\subsection{Study area and materials used}

The study was performed in a section of a forest road located in the municipality of Niquelândia, Goiás state,

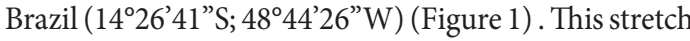
of road was the main access point for a road network used for timber transportation (logs). The origin and destination of the logs was the eucalyptus plantation (1566 ha) and iron-nickel alloy beneficiation plant, respectively, managed by Anglo American Company.

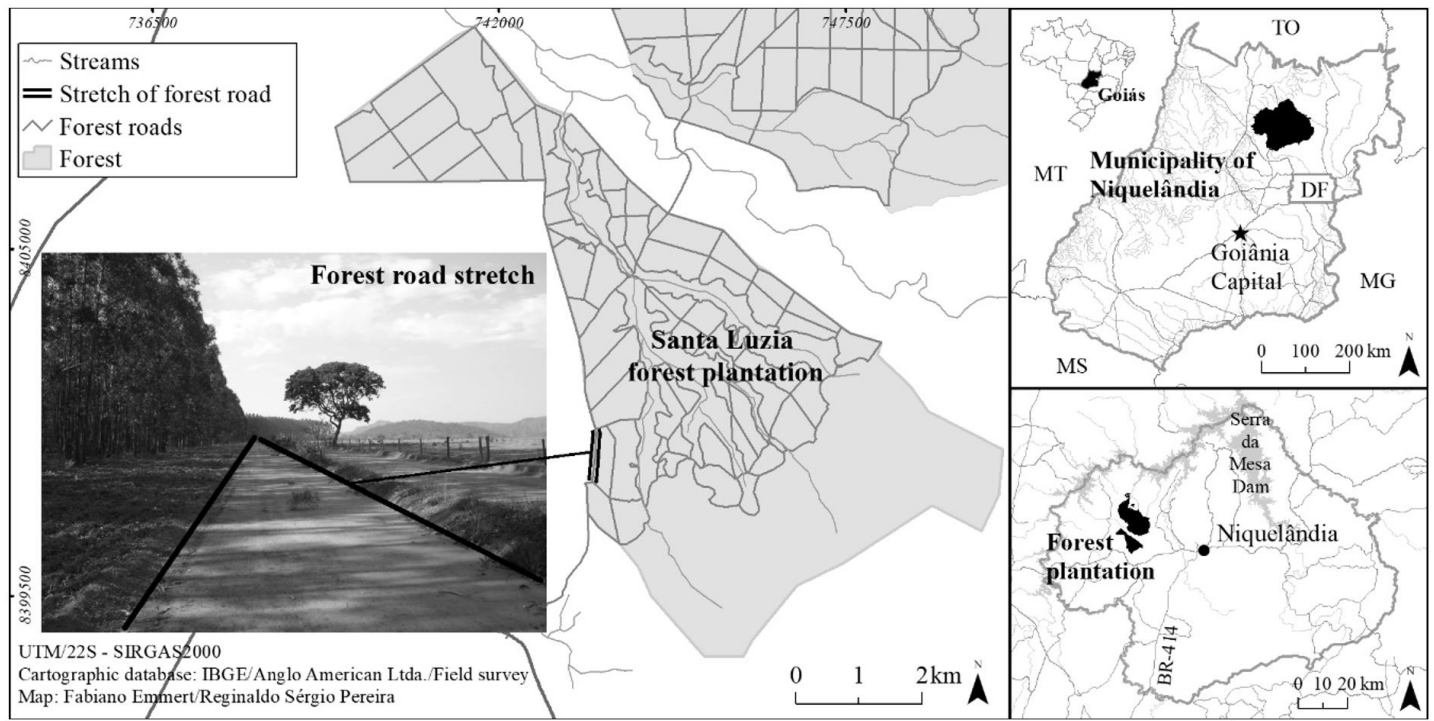

Figure 1. Location of the study area and partial view of the forest road stretch. 
The materials used were local soil (LVAd30) from the forest road and lime (CH-I Araguaia). Soil samples were collected at 19 points at a distance of 45 meters from each other, at $0-0.20 \mathrm{~m}$ depth along the forest road, in three collection sites per sample, on the sides and at the center of the road, using a pickaxe due to the high degree of soil compaction. After collection, the samples were packed in plastic bags, identified, and sent to the Geotechnical Laboratory of the University of Brasilia - UnB for analysis. Hydrated commercial lime, $\mathrm{CH}$-I category, containing $73.37 \%$ calcium oxide $(\mathrm{CaO})$ was used in the experiment.

\subsection{Laboratory experimental program}

In the laboratory, the soil samples were air-dried for $72 \mathrm{hs}$ for determination of the following physical parameters according to the DNIT (2006) norms: (a) specific gravity of solid particles; (b) complete particle size analysis; (c) liquid limit; and (d) plastic limit. Subsequently, the samples were classified with respect to their geotechnical behavior using the Transportation Research Board (TRB) road system according to the DNIT (2006) norms and the Miniature, Compacted, Tropical (MCT) methodology, as in Nogami \& Villibor (2009). The limits established by the ABNT norm (1995) were applied to the particle size distribution of soil fractions, namely: (a) clay $(\phi \leq 0.002 \mathrm{~mm})$; (b) silt $(0.002 \mathrm{~mm}<\phi \leq 0.06 \mathrm{~mm})$; (c) fine sand $(0.06 \mathrm{~mm}<\phi \leq 0.2 \mathrm{~mm})$; (d) medium sand $(0.2 \mathrm{~mm}$ $<\phi \leq 0.6 \mathrm{~mm})$; (e) coarse sand $(0.6 \mathrm{~mm}<\phi \leq 2 \mathrm{~mm})$; and (f) gravel $(\phi>2 \mathrm{~mm})$.

The soil-lime mixture was prepared by adding lime and water to soil at previously defined amounts to achieve a desirable moisture content, followed by manual homogenization and sieving (no. $4.8 \mathrm{~mm}$ ). The mixture was packed in hermetically sealed plastic bags for additional laboratory testing. The percentage of lime employed was $2 \%$, based on dry soil density, according to the results reported in the study by Portelinha et al. (2012).

After preparation of the soil-lime mixture, the following mechanical tests were performed: (a) compaction (ABNT, 1986); (b) unconfined compressive strength UCS (Trindade et al., 2006); and (c) California Bearing Ratio - CBR (DNER, 1994). These assays were also conducted for the local soil without addition of lime.

Determination of the compaction curves and optimum parameters - maximum dry density $\left(\gamma_{\mathrm{dmax}}\right)$ and optimum moisture content $\left(\mathrm{W}_{\mathrm{opt}}\right)$ - was conducted according to the Proctor method. Compaction was performed using the dynamic Proctor mold (internal diameter $=10 \mathrm{~cm}$, height $=12.7 \mathrm{~cm}$, and volume $=1000 \mathrm{~cm}^{3}$ ). Standard, intermediate, and modified compaction efforts were used (Table 1).

For determination of the UCS, cylindrical samples $(\phi=5 \mathrm{~cm} ; \mathrm{h}=10 \pm 0.05 \mathrm{~cm})$ were molded based on the compaction parameters $\left(\mathrm{W}_{\mathrm{opt}}\right.$ and $\left.\gamma_{\mathrm{dmax}}\right)$ and static compaction in an electric press, applying a degree of compaction of $0.3 \%$. When ready, the test samples were wrapped and submitted to wet curing in a chamber with $100 \%$ humidity and $21{ }^{\circ} \mathrm{C}$ temperature for 1,7 , and 28 days. Three samples were molded for each compaction effort and curing period; they were then ruptured in a single compression press at a speed of $1.143 \mathrm{~mm} / \mathrm{min}$, with the UCS value obtained by means of the rupture stresses.

Expansion and CBR values were obtained from the compacted samples according to the compaction parameters $\left(\mathrm{W}_{\mathrm{opt}}\right.$ and $\left.\gamma_{\mathrm{dmax}}\right)$, intermediate and modified efforts, and for the curing time of the highest UCS value. Compaction was performed on five internal layers using a $4.5 \mathrm{~kg}$ pile in a California cylinder $(\phi=15.2$; $\mathrm{h}=12.7 \mathrm{~cm}$ ). The samples prepared in this way were immersed in water for $96 \mathrm{hs}$ (DNER, 1994) and expansion values were measured daily. Subsequently, the samples were ruptured, in triplicate, in a specific press, by the penetration of a standard piston $\left(\mathrm{area}=3 \mathrm{in}^{2}\right)$ at a speed of $1.143 \mathrm{~mm} / \mathrm{min}$, thus obtaining the CBR value.

\subsection{Data analysis}

In order to determine the most accurate results of the UCS test, factorial analysis of variance (ANOVA) was applied followed by Tukey's test. Compaction efforts and curing times were the variables considered,

Table 1. Specification of the soil compaction test according to the ABNT (1986) norm.

\begin{tabular}{lccc}
\hline & \multicolumn{3}{c}{ Compaction Effort } \\
\cline { 2 - 4 } Specifications & Standard & Intermediate & Modified \\
\hline $\begin{array}{l}\text { Compaction pile } \\
(\mathrm{kg})\end{array}$ & 2.50 & 4.54 & 4.54 \\
\hline $\begin{array}{l}\text { Number of layers } \\
\text { Number of blows }\end{array}$ & 3 & 3 & 5 \\
$\begin{array}{l}\text { per layer } \\
\begin{array}{l}\text { Compaction } \\
\text { effort }\left(\mathrm{kg} \mathrm{cm}^{-2}\right)\end{array}\end{array}$ & 26 & 21 & 27 \\
\hline
\end{tabular}


and a significance level of 5\% ( $p>0.05)$ was adopted for all statistical analyses. The CBR and Expansion values were compared with the recommendations of the DNIT (2006) norms for road pavement material, namely: (a) subgrade (CBR $\geq 2 \%$; Expansion $\leq 2 \%$ ); (b) subgrade reinforcement $(\mathrm{CBR} \geq 2 \%$; $\leq 1 \%)$; (c) subbase (CBR $\geq 20 \%$; Expansion $\leq 1 \%$ ); and (d) base $(C B R \geq 80 \%$; Expansion $\leq 0.5 \%$ ).

\section{RESULTS AND DISCUSSION}

Results of the physical characterization of local soil (Table 2) showed predominance of the sand fraction in the samples (>60\%), with a sandy-clayey-silty texture. This soil did not fit into any of the particle size ranges, recommended by the DNIT (2006) norms, for use as grain base for pavements, because it presented less than $25 \%$ of particle size $>2 \mathrm{~mm}$, with reference to the gravel fraction $(5.19 \%)$. The mean value for specific gravity of solid particles was $2.69 \pm 0.03 \mathrm{~kg} \mathrm{dm}^{-3}$.

The importance of the values for liquid limit - LL (25.2\%), plastic limit - PL (18.6\%), and plastic index - PI $(6.6 \%)$ is associated with the volume variation of compacted soils, either by contraction or expansion, which are undesirable characteristics for road construction. The maximum excepted limits established by DNIT (2006) for base materials used in flexible pavements are $\mathrm{LL}=25 \%$ and $\mathrm{PI}=6 \%$.

The local soil was classified as A-4(1) by the Transportation Research Board (TRB) - indicating a satisfactory overall quality for use as material in road subgrades, and as LA' (sandy lateritic) by the MCT system, with the following order of preference: as base of vicinal roads, reinforcement of subgrade, and compacted subgrade. According to Nogami \& Villibor (2009), LA' soils present ease of compaction and adequate cohesion. Silva et al. (2010) highlighted the importance of the mechanical and hydraulic properties of the soil, considered in the MCT classification, for tropical soils.

Figure 2 illustrates the compaction curves of local soil and soil-lime mixture for the three compaction efforts employed. For each compaction effort, addition of lime to the local soil caused a change in the optimal compaction values of the mixture, obtained at the maximum inflection point of the curves, resulting in increased optimum moisture content $\left(\mathrm{W}_{\text {opt }}\right)$ and decreased dry density value $\left(\gamma_{\mathrm{dmax}}\right)$. Similar behavior was reported by Ferreira et al. (2005) and Portelinha et al. (2012) in studies on the stabilization of fine soil with lime.

Both the local soil and the soil-lime mixture responded well to the increase in compaction effort, with a reduction of $W_{\text {opt }}$ and an increase in $\gamma_{\mathrm{dmax}}$ from the standard effort to the modified effort. Trindade et al. (2008) associated increased values of $\gamma_{\mathrm{dmax}}$ with significant improvements in soil engineering properties, such as increased shear strength and erosion resistance. According to Hossain et al. (2007), the soil compaction process increases mechanical strength and cohesion of the particles. Rücknagel et al. (2013) however, highlighted the importance of knowing the maximum mechanical load capacity that a soil can withstand while still preserving its functions.

Figure 3 shows the stress-strain curves obtained in the UCS test, from which it can be inferred that

Table 2. Physical properties and TRB and MCT classifications of soil samples.

\begin{tabular}{|c|c|c|c|c|}
\hline & \multirow{2}{*}{ Analyzed Properties } & \multirow{2}{*}{$\begin{array}{l}\text { Mean Values and } \\
\text { Confidence Interval }\end{array}$} & \multicolumn{2}{|c|}{ Classification } \\
\hline & & & TRB & MCT \\
\hline \multirow{10}{*}{ 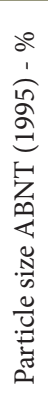 } & Clay $(\phi \leq 0.002 \mathrm{~mm})$ & $21.8 \pm 7.15$ & \multirow{10}{*}{ A-4 (2) } & \multirow{10}{*}{ LA' $^{\prime}$} \\
\hline & Silt $(0.002 \mathrm{~mm}<\phi \leq 0.06 \mathrm{~mm})$ & $12.7 \pm 2.43$ & & \\
\hline & Fine sand $(0.06 \mathrm{~mm}<\phi \leq 0.2 \mathrm{~mm})$ & $46.6 \pm 7.56$ & & \\
\hline & Medium sand $(0.2 \mathrm{~mm}<\phi \leq 0.6 \mathrm{~mm})$ & $9.9 \pm 2.58$ & & \\
\hline & Coarse sand $(0.6 \mathrm{~mm}<\phi \leq 2 \mathrm{~mm})$ & $3.74 \pm 1.27$ & & \\
\hline & $\operatorname{Gravel}(\phi>2 \mathrm{~mm})$ & $5.19 \pm 2.58$ & & \\
\hline & $\gamma_{\mathrm{s}}\left(\mathrm{kg} \mathrm{dm}^{-3}\right)$ & $2.69 \pm 0.03$ & & \\
\hline & $\mathrm{LL}^{*}(\%)$ & $25.2 \pm 4.13$ & & \\
\hline & $\mathrm{PL}^{*}(\%)$ & $18.6 \pm 0.56$ & & \\
\hline & $\mathrm{PI}^{\star}(\%)$ & $6.6 \pm 3.78$ & & \\
\hline
\end{tabular}

Captions: TRB $=$ Transportation Research Board; MCT $=$ Miniature, Compacted, Tropical; ${ }^{*} \gamma_{\mathrm{s}}=$ specific gravity of solid particles; $\mathrm{LL}=$ liquid limit; $\mathrm{PL}=$ plastic limit; $\mathrm{PI}=$ plasticity index $(\mathrm{PI}=\mathrm{LL}-\mathrm{PL})$. 

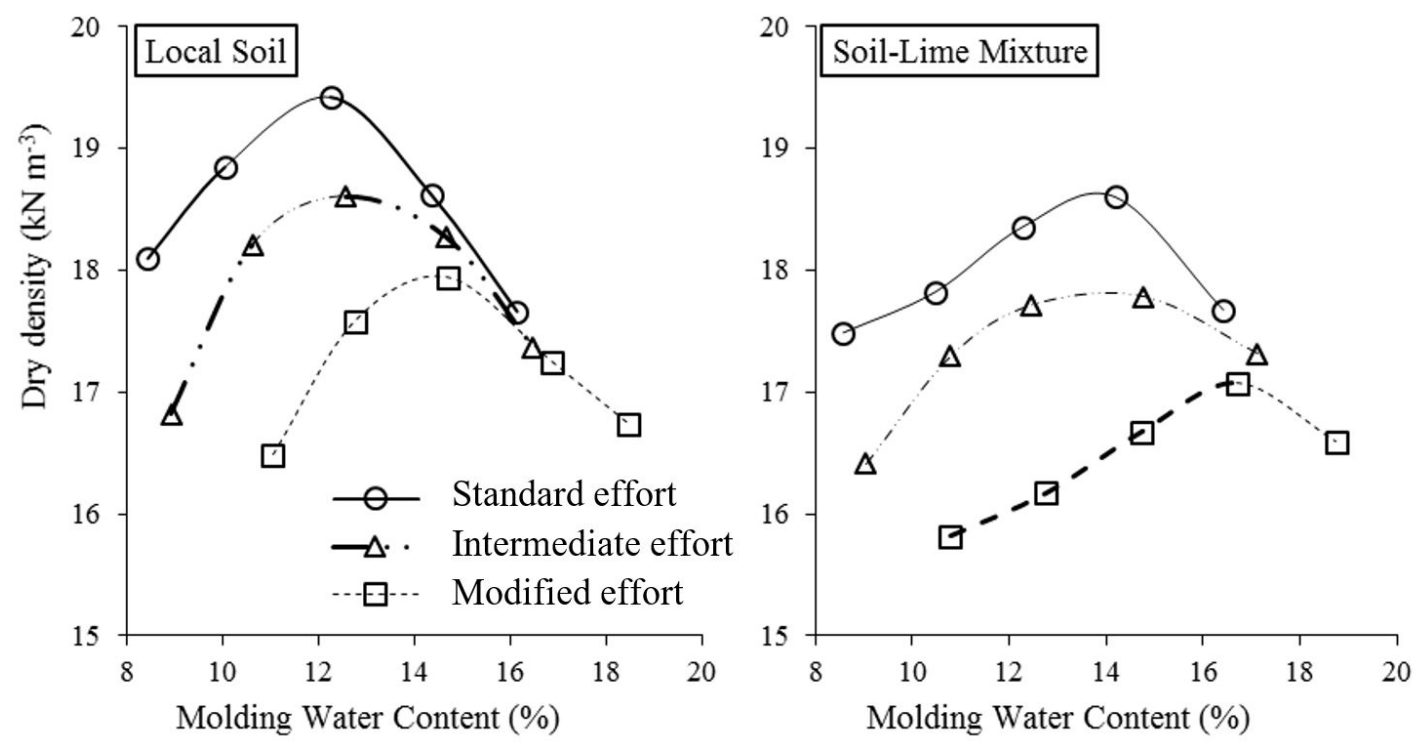

Figure 2. Behavior of soil compaction curves for local soil and soil-lime mixture and their respective optimum values $\left(\mathrm{W}_{\mathrm{opt}}\right.$ and $\left.\gamma_{\mathrm{dmax}}\right)$ : local soil - standard effort $\left(\mathrm{W}_{\mathrm{opt}}=14.45 \% ; \gamma_{\mathrm{dmax}}=17.95 \mathrm{kN} \mathrm{m}^{-3}\right)$; local soil - intermediate effort $\left(\mathrm{W}_{\mathrm{opt}}=12.65 \% ; \gamma_{\mathrm{dmax}}=18.61 \mathrm{kN} \mathrm{m}^{-3}\right)$; local soil - modified effort $\left.\left(\mathrm{W}_{\mathrm{opt}}=12.15 \% ; \gamma_{\mathrm{dmax}}=19.42 \mathrm{kN} \mathrm{m}\right)^{-3}\right)$; soil-lime - standard effort $\left(\mathrm{W}_{\mathrm{opt}}=16.65 \% ; \gamma_{\mathrm{dmax}}=17.10 \mathrm{kN} \mathrm{m}^{-3}\right)$; soil-lime - intermediate effort $\left(\mathrm{W}_{\mathrm{opt}}=14.03 \%\right.$; $\left.\gamma_{\mathrm{dmax}}=17.81 \mathrm{kN} \mathrm{m}^{-3}\right)$; and soil-lime - modified effort $\left(\mathrm{W}_{\mathrm{opt}}=13.80 \% ; \gamma_{\mathrm{dmax}}=18.63 \mathrm{kN} \mathrm{m}^{-3}\right)$.

the higher the compaction effort, both for the local soil and for the soil-lime mixture, the clearer the inflection points of the curves, which show where the samples were ruptured, losing their particle aggregation structure. It is possible to observe that compaction at the modified effort produced complete longitudinal rupture and abrupt breaking of samples of the soil-lime mixtures, showing a higher degree of aggregation of the soil particles by lime. Higher compressive stress values $(\mathrm{kPa})$ were obtained for the soil-lime mixtures as a function of the curing time applied - the longer the curing period, the higher the $\mathrm{kPa}$.

Figure 3 also shows that, for the soil-lime mixtures, the samples presented strain in relation to their height of between 2 and $3 \%$, at the moment of rupture, observed at the maximum inflection point of the stress-strain curves, whereas for the local soil, a strain of $4 \%$ was observed. The practical application of these values lies in the fact that improved layers of forest roads built with this soil-lime mixture, compacted at the modified effort, will resist after 28 days of curing with traffic of up to $786.89 \mathrm{kPa}$, presenting strain of $3 \%$ in its thickness. Greater stress however, may cause cracking and degradation of pavement. The local soil at its best response, that is, compaction at a modified effort, would withstand $385.10 \mathrm{kPa}$, with $4 \%$ strain.

Figure 4 shows the mean values of UCS extracted from the stress-strain curves and statistically differentiated at $5 \%$ significance level by the Tukey's test. Increased values of UCS were observed for all compaction efforts and curing times, with the addition of lime to the local soil followed by mechanical compaction processes. Within the same curing time, compaction at the modified effort resulted in the best UCS results for the soil-lime mixture. However, when the curing factor was considered in such mixtures, the highest UCS values were obtained for the curing times of 7 and 28 days, at the intermediate $(\mathrm{UCS}=578.28 \mathrm{kPa})$ and modified $(\mathrm{UCS}=786.59 \mathrm{kPa}$ ) compaction efforts.

Harichane et al (2011) reported that the reaction between soil and lime results in the formation of cementitious compounds that bind soil particles together and, that generally the UCS value increases with increasing curing time. According to Aldaood et al. (2014), addition of lime to the soil generally improves its geotechnical properties and provokes an immediate exothermic reaction between the $\mathrm{CaO}$ present in lime and soil water, forming calcium hydroxide. The immediate modification that occurs in the engineering properties 

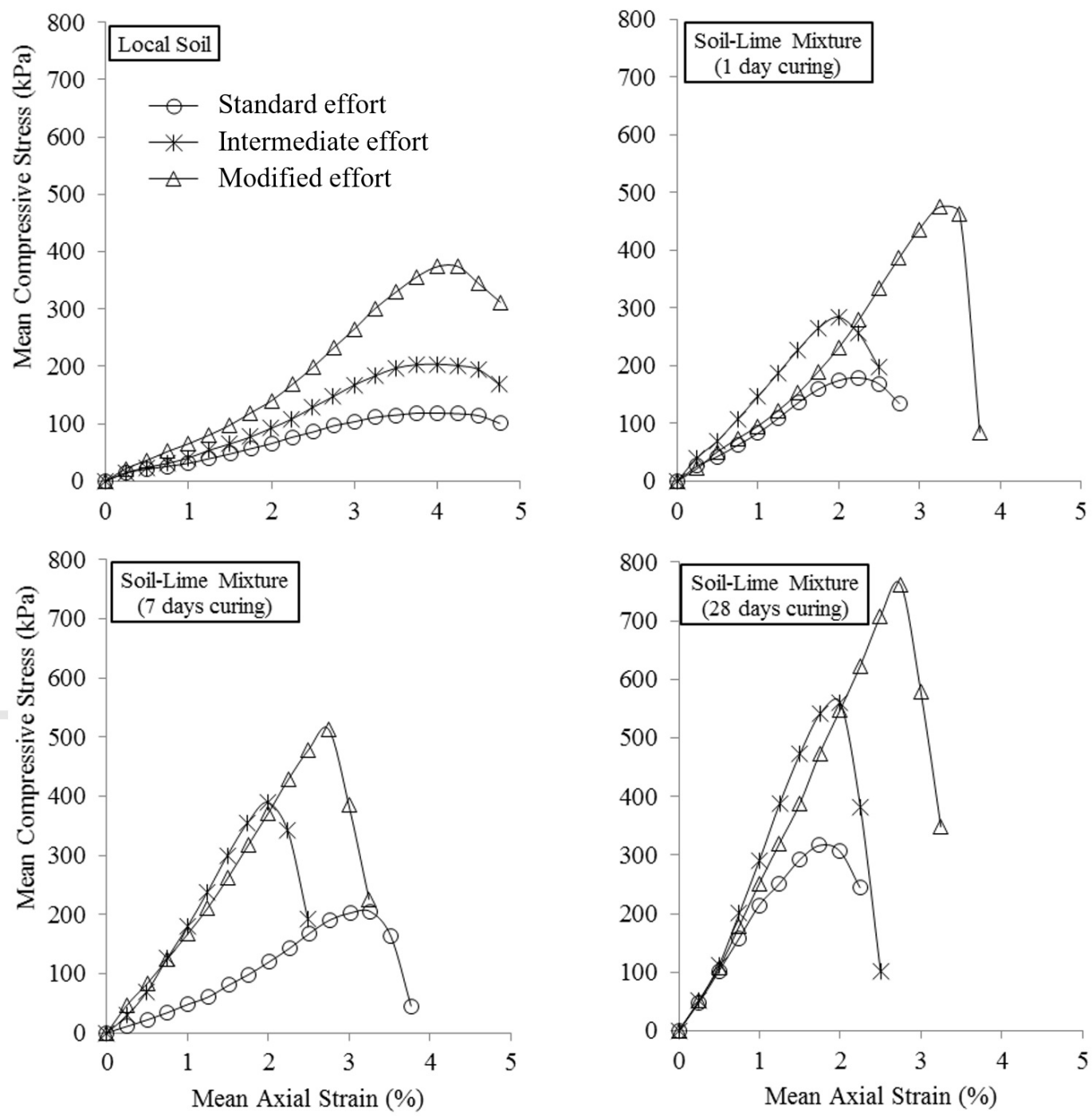

Figure 3. Local soil and soil-lime mixture stress-strain curves.

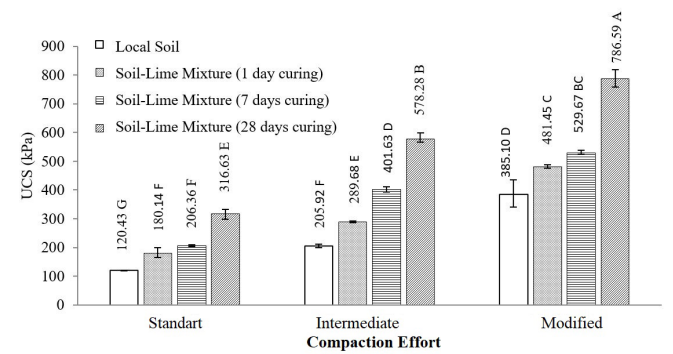

Figure 4. Mean values of UCS, in $\mathrm{kPa}$, of local soil and soil-lime mixture at different compaction efforts and curing times. Means followed by the same letter do not differ at $5 \%$ significance value by the Tukey test; Error bars indicate standard deviation; Least Significant Difference $(L S D)=56.43$. of soils is due to the cation exchange between the ions of the soil clay fraction and the calcium present in lime (Bergaya et al., 2006). Al-Mukhtar et al. (2010) reported the long-term occurrence of pozzolanic reactions in soil-lime stabilization, which are dependent on the curing time and temperature of the mixture. These reactions are responsible for the long-term improvement of the mechanical properties of clays (Pomakhina et al., 2012).

The results of the CBR and Expansion tests for local soil and soil-lime mixtures conducted at the intermediate and modified efforts and 28-day curing time are described in Table 3. Addition of lime to the local soil, followed by compaction, added higher load-bearing capacity to this 
Table 3. CBR and Expansion, in \%, of local soil and soil-lime mixture compacted at intermediate (IE) and modified (ME) efforts and cured for 28 days.

\begin{tabular}{|c|c|c|c|c|c|}
\hline \multirow{2}{*}{ Material } & \multicolumn{2}{|r|}{ IE } & \multicolumn{2}{|c|}{ ME } & \multirow{2}{*}{$\begin{array}{c}\text { Flexible Paved Layer } \\
\text { (According to DNIT, 2006) }\end{array}$} \\
\hline & CBR (\%) & Expansion (\%) & CBR (\%) & Expansion (\%) & \\
\hline Local Soil & 13.52 & 0.03 & 8.00 & 0.06 & $\begin{array}{l}\text { Subgrade and subgrade } \\
\text { reinforcement }\end{array}$ \\
\hline Soil-Lime Mixture & 59.01 & 0.00 & 60.71 & 0.00 & $\begin{array}{l}\text { Subgrade, subgrade } \\
\text { reinforcement and subbase }\end{array}$ \\
\hline
\end{tabular}

Captions: $\mathrm{CBR}=$ California Bearing Ratio; $\mathrm{IE}=$ Intermediate effort; $\mathrm{ME}=$ Modified effort.

construction material, which was shown by the increase in its CBR values: $336 \%$ and $659 \%$ at the intermediate and modified efforts, respectively.

The increase of the compaction effort for the local soil reduced its load-bearing capacity by $40.8 \%$. This occurred because soil particles broke when compacted at the modified effort, leading to soil disintegration and resulting in a lower CBR value. The CBR value of the soil-lime mixture remained practically unchanged as a result of increased compaction effort. Regarding Expansion, the values found for both local soil and soil-lime mixture were numerically negligible. With respect to the classification of the soil-lime mixture as a material to be used on conventional road pavements, according to the DNIT (2006) norms, local soil can be used only as subgrade, whereas the soil-lime mixture can also be used on the subbase layer.

\section{CONCLUSIONS}

Analysis of the results led to the following conclusions: (a) addition of lime modified the mechanical behavior of the local soil, increasing its strength and load-bearing capacity - characteristics desirable for road construction; (b) compaction effort and curing time provided different mechanical responses of the soil-lime mixture, and at the 28-day curing time this mixture can be considered for application as subbase material of flexible road pavements.

\section{ACKNOWLEDGEMENTS}

Angloamerican Company.

\section{SUBMISSION STATUS}

Received: 28 aug., 2015

Accepted: 5 may, 2017

\section{CORRESPONDENCE TO}

\section{Reginaldo Sérgio Pereira}

Departamento de Engenharia Florestal, Universidade de Brasília - UnB, Campus Darcy Ribeiro, CP 04357, Brasília, DF, Brazil e-mail: reginaldosergiopereira@gmail.com

\section{FINANCIAL SUPPORT}

CNPq.

\section{REFERENCES}

Aldaood A, Bouasker M, Al-Mukhtar M. Free swell potential of lime-treated gypseous soil. Applied Clay Science 2014; 102(12): 93-103. http://dx.doi.org/10.1016/j. clay.2014.10.015.

Al-Mukhtar M, Lasledj A, Alcover JF. Behaviour and mineralogy changes in lime-treated expansive soil at $20{ }^{\circ} \mathrm{C}$. Applied Clay Science 2010; 50(2): 191-198. http:// dx.doi.org/10.1016/j.clay.2010.07.023

Associação Brasileira de Normas Técnicas - ABNT. NBR 7182: solo-ensaio de compactação. Rio de Janeiro: ABNT; 1986. $10 \mathrm{p}$.

Associação Brasileira de Normas Técnicas - ABNT. NBR 6502: rochas e solos. Rio de Janeiro: ABNT; 1995. 18 p.

Bergaya F, Theng BKG, Lagaly G, editors. Handbook of clay science. Amsterdam: Elsevier; 2006. 1224 p.

Consoli NC, Lopes LS Jr, Heineck KS. Key parameters for the control of lime stabilized soils. Journal of Materials in Civil Engineering 2009; 21(5): 210-216. http://dx.doi. org/10.1061/(ASCE)0899-1561(2009)21:5(210).

Cristelo N, Glendinning S, Jalali S. Subbases of residual granite soil stabilized with lime. Soils and Rocks 2009; 32(2): 83-88.

Dash SK, Hussain M. Lime stabilization of soils: reappraisal. Journal of Materials in Civil Engineering 2012; 24(6): 707-714. http://dx.doi.org/10.1061/(ASCE)MT.19435533.0000431 
Departamento Nacional de Estradas de Rodagem DNER. ME 049: solos-determinação do índice de suporte califórnia utilizando amostras não trabalhadas. Rio de Janeiro: DNER; 1994. 12 p.

Departamento Nacional de Infraestrutura de Transportes - DNIT. Manual de pavimentação. 3rd ed. Rio de Janeiro: DNIT; 2006. 274 p.

Ferreira RC, Faleiro HT, Freire HJ. Desempenho físicoquímico de solo argiloso estabilizado com cal e silicato de sódio visando aplicação em construções rurais. Pesquisa Agropecuária Tropical 2005; 35(3): 191-198.

Harichane K, Ghrici M, Kenai S, Grine K. Use of natural pozzolana and lime for stabilization of cohesive soils. Geotechnical and Geological Engineering 2011; 29(5): 759-769. http://dx.doi.org/10.1007/s10706-011-9415-z.

Hossain KMA, Lachemi M, Easa S. Stabilized soils for construction applications incorporating natural resources of Papua new Guinea. Resources, Conservation and Recycling 2007; 51(4): 711-731. http://dx.doi.org/10.1016/j. resconrec.2006.12.003.

Machado CC, Sant’Anna GL, Lima DC, Carvalho CAB, Almeida A, Oliveira T. Durabilidade de solos estabilizados quimicamente com vistas á aplicação em estradas florestais. Revista Árvore 2006; 30(6): 981-988. http:// dx.doi.org/10.1590/S0100-67622006000600013.

Millogo Y, Morel JC, Traoré K, Ouedraogo R. Microstructure, geotechnical and mechanical characteristics of quicklimelateritic gravels mixtures used in road construction. Construction \& Building Materials 2012; 26(1): 663-669. http://dx.doi.org/10.1016/j.conbuildmat.2011.06.069.

Nogami JS, Villibor DF. Pavimentos econômicos: tecnologia do uso dos solos finos lateríticos. São Paulo: Arte \& Ciência; 2009. $782 \mathrm{p}$.
Pomakhina E, Deneele D, Gaillot A, Paris M, Ouvrard G. ${ }^{29} \mathrm{Si}$ solid state NMR investigation of pozzolanic reaction occurring in lime-treated Ca-bentonite. Cement and Concrete Research 2012; 42(4): 626-632. http://dx.doi. org/10.1016/j.cemconres.2012.01.008.

Portelinha FHM, Lima DC, Fontes MPF, Carvalho CAA. Modification of a laterictic soil with lime and cement: an economical alternative for flexive pavement layers. Soils and Rocks 2012; 35(1): 51-63.

Rücknagel J, Götze P, Hofmann B, Christen O, Marschall $\mathrm{K}$. The influence of soil gravel content on compaction behaviour and pre-compression stress. Geoderma 2013; 209-210(5): 226-232. http://dx.doi.org/10.1016/j. geoderma.2013.05.030.

Sessions J. Forest road operations in the tropics. Oregon: Springer; 2007. 170 p. http://dx.doi.org/10.1007/978-3540-46393-1.

Silva TO, Carvalho CAB, Lima DC, Calijuri ML, Lani JL, Oliveira TM. Sistemas de classificações geotécnicas de solos: estudo de caso aplicado à rodovia não pavimentada VCS 346, Viçosa, MG. Revista Árvore 2010; 34(2): 313-321. http://dx.doi.org/10.1590/S0100-67622010000200014.

Trindade TP, Carvalho CAB, Lima DC, Barbosa PSA, Silva CHC, Machado CC. Compactação de solos: fundamentos teóricos e práticos. Viçosa: UFV; 2008. 95 p.

Trindade TP, Iasbik I, Lima DC, Minette E, Silva $\mathrm{CHC}$, Carvalho $\mathrm{CAB}$ et al. Estudos laboratoriais do comportamento de um solo residual arenoso reforçado com fibras de polipropileno, visando à aplicação em estradas florestais. Revista Árvore 2006; 30(2): 215-222. http://dx.doi.org/10.1590/S0100-67622006000200008. 